\title{
INSTYTUCJE PUBLICZNE ORAZ STANOWIENIE I EGZEKWOWANIE PRAWA W POLSCE W LATACH 2009-2015 W OCENIE MENEDŻERÓW
}

\section{WPROWADZENIE}

Celem artykułu jest prezentacja i ocena postrzegania przez menedżerów zmian w środowisku instytucjonalnym w Polsce w latach 2009-2015². Jakość funkcjonowania instytucji publicznych i prawodawstwa stanowiących ważna część rozwiązań instytucjonalnych w otoczeniu biznesu w Polsce jest krytykowana przez obywateli, przedsiębiorców i polityków. Krytyczne oceny otoczenia instytucjonalnego, także ze strony zagranicznych obserwatorów, szkodzą międzynarodowej reputacji i konkurencyjności Polski. Przedstawiane oceny zmian w otoczeniu instytucjonalnym oparte sa na własnych badaniach prowadzonych od 1997 r. na celowo dobranej grupie menedżerów średniego i wyższego szczebla posiadających wyższe wykształcenie. Podobnie jak we wcześniejszych badaniach analizę zmian prowadzono w przekrojach rocznych i w obrębie okresów odpowiedzialności legislacyjnej. W niniejszym artykule ocenę sytuacji w latach Sejmu VI i VII kadencji przeprowadzono na tle okresu lat 1998-2015.

Artykuł obok wprowadzenia składa się z trzech głównych punktów oraz podsumowania. W punkcie drugim pokazano dynamikę prawodawstwa w Polsce. W punkcie trzecim zarysowano makroekonomiczny kontekst wpływu otoczenia instytucjonalnego na gospodarkę. Punkt czwarty zawiera prezentację wyników własnych badań empirycznych w odniesieniu do wspomnianych dwóch kadencji Sejmu. Artykuł zamyka podsumowanie.

${ }^{1}$ Artykuł nawiązuje do publikacji autora na ten temat zamieszczonych w „Ruchu Prawniczym, Ekonomicznym i Socjologicznym”. Por. T. Kowalski, C. Wihlborg, V. Vensel, Rozwój środowiska instytucjonalnego w nowych krajach Unii Europejskiej. Przypadek Estonii i Polski, „Ruch Prawniczy, Ekonomiczny i Socjologiczny” 69, 2007, z. 1, s. 151-171, oraz T. Kowalski, Postrzeganie otoczenia instytucjonalnego $w$ Polsce $w$ latach 1997-2009, „Ruch Prawniczy, Ekonomiczny i Socjologiczny" 73, 2011, z. 1, s. 157-177. Autor dziękuje Jackowi Wiewiorowskiemu i Krzysztofowi Szumie za uwagi do manuskryptu, które pomogły poprawić tekst. Wszelkie pozostałe jeszcze niedoskonałości artykułu obciążają wyłącznie autora. 


\section{LICZBOWY WYMIAR PRAWODAWSTWA W LATACH 2009-2015}

W okresie objętym analizą odbyły się dwie kampanie wyborcze do Sejmu i Senatu. Październikowe wybory 2015 r. kończą okres dwóch pełnych kadencji odpowiedzialności legislacyjnej koalicji Platformy Obywatelskiej i Polskiego Stronnictwa Ludowego, które dysponowały większością głosów w okresie październik 2007 - październik 2015 (tab. 1).

Tabela 1

Wyniki wyborów parlamentarnych w latach 2007-2011 i główne partie reprezentowane w Sejmie i Senacie (w \%)

\begin{tabular}{|l|c|c|}
\cline { 2 - 3 } \multicolumn{1}{c|}{} & Październik 2007* & Październik 2011 \\
\hline Frekwencja & 53,9 & 48,92 \\
\hline PSL & 8,9 & 8,36 \\
\hline SLD & 13,1 & 8,24 \\
\hline PiS & 32,1 & 29,89 \\
\hline PO & 41,5 & 39,18 \\
\hline RP & - & 10,02 \\
\hline
\end{tabular}

Oznaczenia: *przedterminowe wybory, PSL - Polskie Stronnictwo Ludowe, SLD - Sojusz Lewicy Demokratycznej, PiS - Prawo i Sprawiedliwość, PO - Platforma Obywatelska, RP - Ruch Palikota.

Źródło: na podstawie danych Państwowej Komisji Wyborczej.

$\mathrm{Z}$ danych w tabeli 1 oraz na podstawie analizy zmian w strukturze Sejmu, jakie zaszły w czasie VII kadencji, wynika, że efektywna większość głosów koalicji rządzącej nie stwarzała warunków do opracowania i wdrożenia fundamentalnych zmian ustawodawczych.

Wykresy 1 i 2 przedstawiają ilościowe wymiary działalności legislacyjnej odnoszacej się do sfery gospodarczej w Polsce w latach 1990-2015. Działalność legislacyjna cechuje naturalna cykliczność wynikająca z rytmu wyborów parlamentarnych. Dane zestawione na wykresach 1 i 2 potwierdzaja tę właściwość. W latach wyborczych i bezpośrednio po nich liczba nowych aktów prawnych była z reguły mniejsza. Czynnikiem silnie wpływającym na aktywność legislacyjną były ważne wyzwania związane z:

- reformami systemowymi (1990-1993);

- pracami nad nową konstytucją 1997 r. i ustawami okołokonstytucyjnymi;

- negocjacjami członkowskimi (1999-2004);

- obowiązkami (po 2004) wynikającymi z członkostwa w UE;

- zagrożeniami i skutkami globalnego kryzysu finansowego lat 2008-2009.

Działalność Sejmu VI i VII kadencji w latach 2007-2011 i 2011-2015 to jedyny po 1989 r. okres, w którym ta sama większość mogła kontynuować odpowiedzialność legislacyjna. Lata po 2007 r., a więc kryzys globalny lat 2008-2009 i trudny, szczególnie dla Unii Europejskiej, okres pokryzysowy, choć bezpośrednio nie był dla Polski tak dotkliwy jak w sąsiednich krajach, zdominował uwagę rządu i wywarł pośrednio negatywny wpływ na wzrost gospodarczy. Wymógł także liczne zmiany w sferze polityki gospodarczej i wymagał zwiększonej aktywności legislacyjnej. 


\section{Wykres 1}

Liczba ważniejszych aktów prawnych wprowadzonych w życie w Polsce w latach 1990-2015*

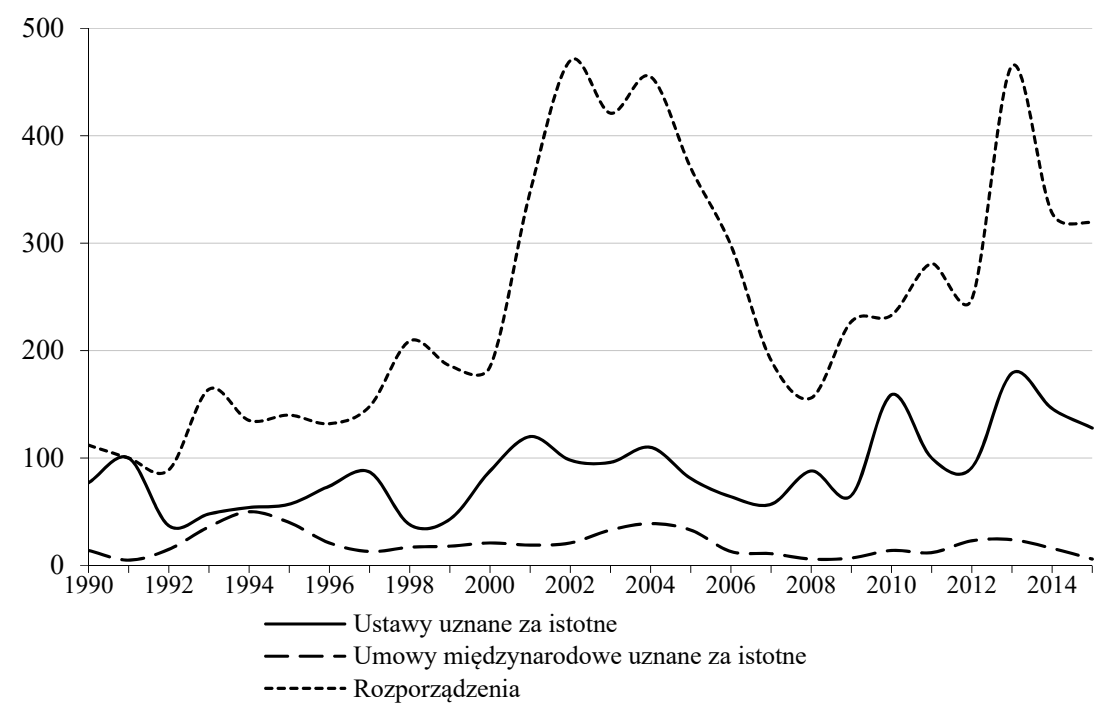

*Dane dotyczące 2015 r. obejmują tylko działalność legislacyjną Sejmu VII kadencji.

Źródło: obliczenia własne na podstawie bazy Lexus.

Wykres 2

Dynamika działalności legislacyjnej w Polsce w latach 1990-2015* (w \%)

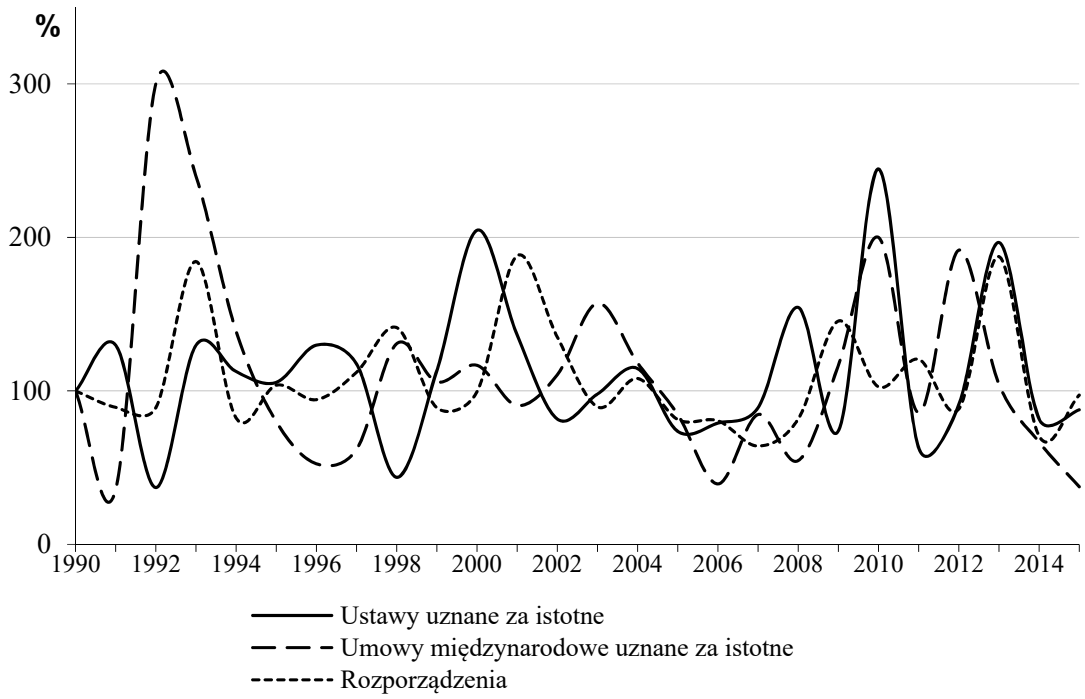

*Dane dotyczące 2015 r. obejmują tylko działalność legislacyjną Sejmu VII kadencji.

Źródło: obliczenia własne na podstawie bazy Lexus. 
Analizując dynamikę tworzenia aktów prawnych w Polsce, należy zauważyć, że znaczna ich część powstawała w reakcji na błędy i niedociagnięcia powstałe $\mathrm{w}$ trakcie przygotowywania i procedowania ustaw. W rezultacie liczne ustawy wymagały nowelizacji ${ }^{2}$. Powszechną praktyką było szerokie uzupełnianie ustaw aktami niższego rzędu. Niewystarczająca jakość stanowionego prawa i mnogość przepisów w połączeniu z kulturą niskiego zaufania w relacjach między agendami publicznymi i sektorem prywatnym tworzą łącznie niesprzyjający klimat dla przedsiębiorczości. Z ekonomicznego punktu widzenia podnosi to koszty transakcyjne ${ }^{3}$, zwiększa niepewność i szkodzi innowacyjności. Taki klimat jest szczególnie odczuwalny przez małe i średnie przedsiębiorstwa. Niska jakość prawa i jego niestabilność prowadzą do obniżenia poszanowania prawa i powagi agend publicznych. Wzrost komplikacji, a nierzadko sprzeczności w prawie stwarzają bodźce do zachowań patologicznych" Poprzez mechanizm zależności od ścieżki (zob. pkt III) negatywnie wpływają więc na kapitał społeczny i mogą trwale zniekształcić długoterminowe decyzje w sektorze prywatnym.

\section{MAKROEKONOMICZNY KONTEKST WPLYWU OTOCZENIA INSTYTUCJONALNEGO NA GOSPODARKĘ}

Zwiąki między rozwojem instytucjonalnym a postępem i sprawnościa gospodarki od dłuższego czasu przyciagają uwagę ekonomistów ${ }^{5}$. Do tego nurtu zainteresowań należą także współzależności między otoczeniem instytucjonalnym a przebiegiem reform systemowych, które są przedmiotem studiów w ramach prawa ${ }^{6}$, ekonomii porównawczej ${ }^{7}$ i nowej ekonomii instytucjonalnej $(\mathrm{NEI})^{8}$. Wychodząc z ustaleń NEI, w opracowaniu przyjęto, że zrozumienie

${ }^{2}$ Por. S. Wronkowska, Proces prawodawczy dwóch dekad - sukcesy i niepowodzenia, „Ruch Prawniczy, Ekonomiczny i Socjologiczny" 71, 2009, z. 2, s. 116-117.

${ }^{3}$ Por. K. Mroczek-Dabrowska, Transaction costs and their impact on internationalization degree - theoretical framework, „Economics and Business Review”16(2), 2016, nr 1, s. 3-14.

${ }^{4}$ Por. T. Kowalski, C. Wihlborg, Problems of governance and institutional environment in the European transition economies, w: T. Kowalski, S. Letza and C. Wihlborg (eds.), Institutional Change in the European Transition Economies. The Case of Poland, Wyd. UE w Poznaniu.

${ }^{5}$ Por. D. Acemoglu, J. A. Robinson, Why Nations Fail? The Origins of Power, Prosperity and Poverty, Profile Books, London 2012; J. Polowczyk, The institutional perspective in strategic management, Proceedings of The International Jubilee Scientific Conference "Economics and Management in the 21st Century - Solutions for Sustainability and Growth", Tsenov Academic Publishing House, Svishtov 2011, s. 156-162; E. D. Beinhocker, The Origin of Wealth. Evolution, Complexity and the Radical Remaking of Economics, Harvard Business School Press, Boston 2006.

${ }^{6}$ Por. P. Winczorek, Subiektywne spojrzenie na przemiany ustrojowe lat 1989-2009, „Ruch Prawniczy, Ekonomiczny i Socjologiczny" 71, 2009, z. 2, s. 29-50; S. Wronkowska, op. cit.

${ }^{7}$ L. Balcerowicz, Socjalizm, kapitalizm, transformacja: szkice z przełomu epok, WN PWN, Warszawa 1997; A. Aslund, How Capitalism Was Built. The Transformation of central and Eastern Europe, Russia and Central Asia, Cambridge Univ. Press, Cambridge 2007; K. Szarzec et al., Instytucje w krajach transformujacych sie, Global Development Research Group, 2014, June 2.

${ }^{8}$ M. Ratajczak, Transformacja ustrojowa $w$ świetle ustaleń ekonomii instytucjonalnej, „Ruch Prawniczy, Ekonomiczny i Socjologiczny” 71, 2009, z. 2, s. 233-251. Na ten temat zob. także J. Osińskiego (red.), Kapitalizm czy kapitalizmy, Oficyna Wydawnicza, SGH, Warszawa 2012. 
transformacji rynkowej, a w tym szczególnie jej barier instytucjonalnych, wymaga zastosowania koncepcji zależności od ścieżki (path dependence). Świadomość istnienia zjawiska zależności od ścieżki wnosi do analiz ekonomicznych wymiar historyczności. Kontekst ten stwarza też ciekawą perspektywę badawczą zarówno w zakresie podejścia opisowo-diagnostycznego, jak i normatywnego.

Według Paula A. Davida pojęcie zależność od ścieżki odnosi się do dynamicznych cech procesów alokacyjnych ${ }^{9}$. Autor ten uważa, że „zależność od ścieżki może być definiowana zarówno w odniesieniu do relacji pomiędzy dynamika procesu a skutkami, do których ten proces zmierza lub w sensie redukowania rozkładu prawdopodobieństwa danego stochastycznego procesu”. David rozróżnia procesy podlegające ścieżce zależności i takie, która sa wolne od tej właściwości (path independent processes). Te drugie to takie, które albo mają tę właściwość endemicznie albo wyzwoliły się z bezwładności przez odpowiednie działanie. W. Brian Artur wskazuje na istnienie pewnej klasy systemów (locked-in), które w specyficznej równowadze utknęły w niekorzystnym dla swego rozwoju położeniu ${ }^{10}$.

Pod koniec lat osiemdziesiątych XX w. Polska i inne kraje regionu trwały w specyficznym położeniu, którego przezwyciężenie wymagało systemowej interwencji. Właśnie w takim kontekście należy widzieć wyjściowe reformy instytucjonalne z przełomu 1989 i 1990 r. i działania reformatorskie w następnych latach. Zależność od ścieżki nie odnosiła więc tylko do stanu i struktury kapitału rzeczowego (fizycznego) i finansowego. Silnie determinowała bowiem także postawy poznawcze ${ }^{11}$, oczekiwania, relacje społeczne i wyrażała się w zasobach wiedzy i umiejętności. Obejmowała więc to, co w ekonomii nazywamy kapitałem ludzkim i kapitałem społecznym ${ }^{12}$.

Zależność od ścieżki i powiązania różnych czynników i zasobów kapitału można wyrazić za pomoca funkcji produkcji typu Cobb-Douglasa ${ }^{13}$. Przyjmując stałe stopy zwrotu względem skali i dla uproszczenia pomijajac subskrypt czasu produkcję (produkt krajowy brutto (PKB)) - Y można zapisać jako funkcję ${ }^{14}(1)$ :

$$
Y=A H^{a} K^{b} N^{c} L^{1-a-b-c},
$$

\footnotetext{
${ }^{9}$ P. A. David, Path dependence, its critics and the quest for 'historical economics', 2005, s. 4, ResearchGate, https://www.researchgate.net/publication/23742679 [dostęp: 20.07.2016].

${ }^{10} \mathrm{~W}$. B. Arthur, Competing technologies, increasing returns, and lock-in by historical event, „The Economic Journal” 99(394), March 1989, s. 116-131 (tłum. - T.K.).

${ }^{11}$ D. Kahnemann, Pułapki myślenia. O myśleniu szybkim i wolnym, Media Rodzina, Poznań 2012.

${ }_{12}$ Por. H. Januszek (red.), Kapitat społeczny: aspekty teoretyczne i praktyczne, Wyd. AE, Poznań 2004.

${ }^{13}$ Por. T. Gylfason, E. Hochreiter, Growing Together: Croatia and Latvia, CESifo Working Paper, October, no. 3202, 2010; R. Rapacki, M. Próchniak, Wzrost w gospodarczy w krajach Europy Środkowo-Wschodniej na tle wybranych krajów wschodzacych, „Gospodarka Narodowa” 2012, nr 1-2.

${ }^{14}$ T. Kowalski, Globalization and Transformation in Central European Countries: The Case of Poland, Poznan Univ. of Economics Press, Poznan 2013, s. 102-103.
} 
gdzie:

$A$ - łączna produktywność czynników (TFP),

$H$ - kapitał ludzki,

$K$ - kapitał fizyczny (rzeczowy),

$N$ - zasoby naturalne (w tym ziemia),

$L$ - siła robocza,

$a, b, c$ - elastyczności produkcji (PKB) względem wyodrębnionych w (1) czynników.

Dzieląc obustronnie równanie (1) przez $L$, wyrażamy produkt per capita (2) jako funkcję łącznej produktywności czynników $A$, kapitału ludzkiego per capita $H / L$, kapitału rzeczowego per capita $K / L$ i zasobów naturalnych per capita $N / L$.

$$
\frac{Y}{L}=A\left(\frac{H}{L}\right)^{a}\left(\frac{K}{L}\right)^{b}\left(\frac{N}{L}\right)^{c}
$$

Przyjmujemy dla uproszczenia, że pod koniec lat osiemdziesiątych Polska i kraje Europy Środkowej, ponieważ miały podobne doświadczenia systemowe i zbliżone zasoby kapitałowe, swoją nową trajektorię rozwojową musiały oprzeć na zmianach instytucjonalnych. W równaniu (2) ich ilościowy wpływ, obok postępu technologiczno-organizacyjnego, ucieleśniony jest w parametrze $A$. Parametr $A$ przedstawia tę część wzrostu PKB, która nie wynika z nakładów pracy (liczby łaccznie przepracowanych godzin) lub nakładów kapitału rzeczowego i zasobów naturalnych. Im wyższa była postrzegana i faktyczna łączna produktywność czynników, tym dana gospodarka przyciagała więcej zewnętrznego kapitału lub była zdolna mobilizować więcej kapitału krajowego z przeznaczeniem na inwestycje zwiększajace szanse wzrostu gospodarczego. Korzystając z typowych założeń przyjmowanych w literaturze przedmiotu ${ }^{15}$, tj. przyjmując, że $c=0$ i że elastyczność produkcji $Y$ względem kapitału fizycznego wynosi ${ }^{1} / 3$, a w konsekwencji elastyczność $Y$ względem kapitału ludzkiego równa jest ${ }^{2} / 3$, równanie (2) można zapisać jako $(3)^{16}$ :

$$
\frac{Y}{L}=A^{\frac{1}{1-b}}\left(\frac{H}{L}\right)^{\frac{a}{1-b}}\left(\frac{K}{Y}\right)^{\frac{b}{1-b}}=A^{1.5} \sqrt{\left(\frac{K}{Y}\right)}\left(\frac{H}{L}\right) .
$$

Formuła (3) wskazuje na wzajemne zależności między mierzalnymi i niemierzalnymi bezpośrednio czynnikami wzrostu. Napływ bezpośrednich inwestycji zagranicznych niewątpliwie jest funkcją wielu czynników, jednakże zdolność danego kraju do wyzwolenia się od wyjściowej zależności od ścieżki była ważnym wyróżnikiem wśród rywalizujących ze sobą gospodarek. Im wyższa była skokowa poprawa jakości tego otoczenia i oczekiwana w przyszłości ścieżka jego doskonalenia, tym inwestorzy mogli wydłużać horyzont inwestycji i formułować bardziej umiarkowane wymagane stopy zwrotu z inwestycji.

15 Por. T. Gylfason, E. Hochreiter, op. cit.; R. Rapacki, M. Próchniak, op. cit.

16 Por. T. Gylfason, E. Hochreiter, op. cit, s. 8-9. 
Otoczenie instytucjonalne zmodyfikowane w pierwszym okresie przez reformatów przynajmniej częściowo pozwoliło na odrzucenie dziedzictwa praktyk ugruntowanych przez lata działania systemu nierynkowego. W kolejnych latach tempo i zakres koniecznych zmian w funkcjonowaniu agend publicznych i prawodawstwa zmniejszyły się. Z jednej strony było to efektem zjawiska zmęczenia reformami, z drugiej zaś - skutkiem natury procesu politycznego. Podsumowując, można stwierdzić, że faktyczne tempo rozwoju gospodarczego obok wpływu klasycznych ilościowych czynników wzrostu było wynikową:

- autonomicznych dostosowań w sferze kapitału ludzkiego i społecznego wywołanych pierwotnym impulsem reformatorskim;

- stylu i jakości funkcjonowania agend państwa;

- jakości tworzonego prawa, kultury i sprawności jego egzekwowania.

W punkcie IV zaprezentowano i poddano analizie wyniki ankietowe odnoszące się do dwóch ostatnich aspektów otoczenia instytucjonalnego gospodarki.

\section{PERCEPACJA STANU I ZMIAN W OTOCZENIU INSTYTUCJONALNYM}

\section{Zakres i metoda badania}

Badania ankietowe prowadzono corocznie od $1997 \mathrm{r} .{ }^{17}$ na nielosowej próbie ponad 140 menedżerów z wyższym wykształceniem. W niniejszym opracowaniu zaprezentowano wyniki odnoszące się do lat 2009-2015 na tle całego okresu od 1997 r. Badanie prowadzono każdorazowo pod koniec roku. W 2015 r., z uwagi na skutki wyborów do Sejmu i Senatu, w kwestionariuszu wyraźnie zaznaczono, że ocenie respondentów podlega okres od stycznia do października tego roku. W celu zebrania informacji niezmiennie wykorzystano kwestionariusz Bornera, Brunetti i Wedera ${ }^{18}$. Kwestionariusz obejmował łacznie 16 pytań lub stwierdzeń, do których respondenci, stosownie do swych przekonań, odnosili się zaznaczając odpowiedzi opisowe, którym przyporządkowano numeryczne oceny (por. tab. 2-5).

Pierwsza grupa pytań dotyczy ocen instytucji publicznych i funkcjonowania prawa w Polsce. Pytania zamieszczone w tabeli 2 z ekonomicznego punktu widzenia pośrednio dotyczyły kwestii wpływu działania agend publicznych na koszty transakcyjne. Druga grupa stwierdzeń i pytań odnosi się do percepcji jakości szeroko rozumianego stanowienia prawa (tab. 3). Pytania ankietowe akcentują kwestie ocen stopnia nieokreśloności procedur legislacyjnych. Z ekonomicznego punktu widzenia mają one również wpływ na koszty transakcyjne i na ryzyko i odczucia niepewności mające znaczenie przy podejmowaniu decyzji inwestycyjnych.

${ }_{17}$ T. Kowalski, Postrzeganie otoczenia instytucjonalnego..., s. 157-177. Autor dziękuje A. Wojciechowskiej-Refermat za uwagi, pomoc i statystyczne i graficzne opracowanie danych.

18 S. Borner, A. Brunetti, B. Weder, Political Credibility and Economic Development, Macmillan Press Ltd., London 1995, s. 172-178. 


\section{Tabela 2}

Instytucje publiczne i funkcjonowanie prawa w Polsce

\begin{tabular}{|c|c|c|}
\hline Symbol & Pytanie & Warianty odpowiedzi \\
\hline I. 1 & $\begin{array}{l}\text { Proszę ocenić następujące zdanie odnośnie do Polski: „Pra- } \\
\text { wa i przepisy są tak skomplikowane, niejasne a czasami } \\
\text { wykluczające się, że nie sposób stosować się do nich nor- } \\
\text { malnie. Stąd też urzędnicy państwowi mogą zawsze zna- } \\
\text { leźć sposoby i środki, by utrudnić Tobie życie (duże opóź- } \\
\text { nienia, arbitralne decyzje, etc.”). Taka sytuacja zdarza się: }\end{array}$ & \multirow{5}{*}{$\begin{array}{l}\text { - nigdy } 1 \\
\text { - rzadko } 2 \\
\text { - czasami } 3 \\
\text { - często } 4 \\
\text { - przeważnie } 5 \\
\text { - zawsze } 6\end{array}$} \\
\hline I. 2 & $\begin{array}{l}\text { „Załóżmy, że napotykasz wyraźnie nieuczciwe postępo- } \\
\text { wanie lub urzędnik państwowy domaga się od Ciebie } \\
\text { łapówki. Czy przeciwstawiłbyś się temu i poinformował } \\
\text { o tym jego zwierzchników lub dochodził swoich praw na } \\
\text { drodze sądowej?” }\end{array}$ & \\
\hline I. 3 & $\begin{array}{l}\text { Proszę oceń następujące zdanie odnośnie do Polski: „Jako } \\
\text { przedsiębiorca zawsze obawiasz się popełnienia małej 'po- } \\
\text { myłki' w dokumentach przedkładanych władzom lokalnym } \\
\text { i fiskalnym, ponieważ te 'pomyłki' mogą być wykorzystane } \\
\text { przez urzędników państwowych by domagać się łapówek } \\
\text { bądź stanowić podstawę do szantażu”. To zdarza się: }\end{array}$ & \\
\hline I. 4 & $\begin{array}{l}\text { Czy znajomość osobista z urzędnikiem zajmującym się } \\
\text { Twoją sprawą może przyspieszyć jej bieg? }\end{array}$ & \\
\hline I. 5 & $\begin{array}{l}\text { Czy znajomość osobista z urzędnikiem zajmującym się } \\
\text { Twoją sprawą może wpłynąć na jego decyzję (wysokość } \\
\text { podatku, wydanie licencji...)? }\end{array}$ & \\
\hline
\end{tabular}

Źródło: opracowanie własne na podstawie S. Borner, A. Brunetti, B. Weder, Political Credibility..., op. cit.

Tabela 3

Stanowienie prawa w Polsce

\begin{tabular}{|c|c|c|}
\hline Symbol & Pytanie & Warianty odpowiedzi \\
\hline S.1 & $\begin{array}{l}\text { Czy jako przedsiębiorca masz regularnie do } \\
\text { czynienia z niespodziewanymi zmianami } \\
\text { prawa i/lub przepisów, które mogą poważnie } \\
\text { wpłynać na Twoje interesy? Zmiany w pra- } \\
\text { wie i przepisach są: }\end{array}$ & $\begin{array}{l}\text { - całkowicie przewidywalne } 1 \\
\text { - wysoce przewidywalne } 2 \\
\text { - dość przewidywalne } 3 \\
\text { - często nieprzewidywalne } 4 \\
\text { - przeważnie nieprzewidywalne } 5 \\
\text { - całkowicie nieprzewidywalne } 6\end{array}$ \\
\hline S. 2 & $\begin{array}{l}\text { Czy jako przedsiębiorca jesteś oficjalnie } \\
\text { bądź nieoficjalnie informowany (przez pra- } \\
\text { sę, organizacje zrzeszające przedsiębiorców) } \\
\text { o nowym prawie i/lub planach zmiany obo- } \\
\text { wiązującego prawa lub przepisów? }\end{array}$ & \multirow{3}{*}{$\begin{array}{l}\text { - nigdy } 1 \\
\text { - rzadko } 2 \\
\text { - czasami } 3 \\
\text { - często } 4 \\
\text { - przeważnie } 5 \\
\text { - zawsze } 6\end{array}$} \\
\hline S.3 & $\begin{array}{l}\text { Czy w przypadku znacznych zmian w pra- } \\
\text { wie wpływających na Twoje interesy możesz } \\
\text { przedstawić pośrednio swoje obawy i/lub } \\
\text { bezpośrednio konsultować te zmiany? }\end{array}$ & \\
\hline S.4 & $\begin{array}{l}\text { Czy rządowe zapowiedzi realizowania ważnych } \\
\text { projektów, do których się publicznie zobowiązał } \\
\text { (np. nowe prawo podatkowe, rozbudowa infra- } \\
\text { struktury, cele budżetowe) są godne zaufania? }\end{array}$ & \\
\hline
\end{tabular}

Źródło: jak w tabeli 2. 
Trzecia grupa pytań i stwierdzeń dotyczy percepcji egzekwowania prawa w Polsce (tab. 4). Obszar ten niezmiennie stanowi powód do troski we wszystkich krajach transformacji. Jest postrzegany jako jeden z najbardziej zaniedbanych w stosunku do oczekiwań i do standardów najwyżej rozwiniętych gospodarek ${ }^{19}$. Niska ocena sprawności aparatu sądowego jest jedną z najczęściej wskazywanych słabości nowych gospodarek rynkowych ${ }^{20}$.

\section{Tabela 4}

Egzekwowanie prawa w Polsce

\begin{tabular}{|c|c|c|}
\hline Symbol & Pytanie & Warianty odpowiedzi \\
\hline E.1 & $\begin{array}{l}\text { Załóżmy, że Twój prywatny spór trafia do sądu. Dowody } \\
\text { jednoznacznie świadczą na Twoją korzyść. Czy wierzysz, } \\
\text { że wyznaczony sędzia obiektywnie wymierzy sprawiedli- } \\
\text { wość? }\end{array}$ & \multirow{4}{*}{$\begin{array}{l}\text { - nigdy } 1 \\
\text { - rzadko } 2 \\
\text { - czasami } 3 \\
\text { - często } 4 \\
\text { - przeważnie } 5 \\
\text { - zawsze } 6\end{array}$} \\
\hline E.2 & $\begin{array}{l}\text { Proszę rozważ następujące zdanie w odniesieniu do Pol- } \\
\text { ski: „Strona, która więcej płaci (łapówki, lepsi prawnicy) } \\
\text { wygra sprawę. Nawet jeżeli dowody sa jednoznaczne, } \\
\text { pieniądze mogą zmienić werdykt”. To zdarza się: }\end{array}$ & \\
\hline E.3 & $\begin{array}{l}\text { Czy jest bez znaczenia, który sędzia decyduje o sprawie? } \\
\text { Czy może pomóc osobista znajomość z wyznaczonym do } \\
\text { sprawy sędzią? }\end{array}$ & \\
\hline E. 4 & $\begin{array}{l}\text { Gdybyś został niesprawiedliwie potraktowany w sądzie } \\
\text { (z powodu domagania się łapówki lub werdyktu, którego } \\
\text { jednoznacznie nie oceniasz sprawiedliwym), czy wniós- } \\
\text { łbyś sprawę do wyższej instancji? }\end{array}$ & \\
\hline
\end{tabular}

Źródło: jak w tabeli 2a.

Za pomoca ankiety respondenci byli także pytani o ich ocenę zmian ogólnego poziomu niepewności w wyodrębnionych w badaniu obszarach otoczenia instytucjonalnego w Polsce (tab. 5). Pytania zawarte w tabeli 5 maja retrospektywny charakter kroczący; np. odpowiedzi udzielone w ankiecie w 2015 r. odnoszą się do percepcji sytuacji w okresie 2005-2015. Określone w ten sposób dziesięcioletnie średnie kroczące są aproksymacją długotrwałych tendencji $\mathrm{w}$ ocenach niepewności $\mathrm{w}$ otoczeniu instytucjonalnym w Polsce.

${ }_{19}$ Por. T. Kowalski, C. Wihlborg, Problems of governance..., s. 14-29.

${ }_{20}$ Por. K. Schwab, Global Competitiveness Report 2015-2016, World Economic Forum, Geneva 2016. 


\section{Tabela 5}

Percepcja zmian niepewności w otoczeniu instytucjonalnym w Polsce

\begin{tabular}{|c|c|c|}
\hline Symbol & Pytanie & Warianty odpowiedzi \\
\hline I & $\begin{array}{l}\text { Czy myślisz, że w ciagu ostatnich } 10 \text { lat niepewność co do } \\
\text { działania agend rządowych }\end{array}$ & \multirow{3}{*}{$\begin{array}{l}\text { - zwiększyła się } 1 \\
\text { - pozostaje na tym } \\
\text { samym poziomie } 2 \\
\text { - zmniejszyła się } 3\end{array}$} \\
\hline $\mathrm{S}$ & $\begin{array}{l}\text { Czy myślisz, że w ciagu ostatnich } 10 \text { lat niepewność } \\
\text { w stanowieniu prawa }\end{array}$ & \\
\hline $\mathrm{E}$ & $\begin{array}{l}\text { Czy uważasz, że w trakcie ostatnich } 10 \text { lat niepewność } \\
\text { w egzekucji prawa }\end{array}$ & \\
\hline
\end{tabular}

Źródło: jak w tabeli 2.

\section{Wyniki badań ankietowych}

\subsection{Przekrój roczny}

Tabele 6 i 7 zawierają zestawienie kierunków zmian średniej arytmetycznej odpowiedzi na pytania ankietowe w ujęciu rocznym. Znak minus (-) oznacza pogorszenie się sytuacji w stosunku do poprzedniego roku; znak plus (+) oznacza poprawę, a znak plus/minus (+/-) brak lub niewielkie zmiany w porównaniu z rokiem poprzednim. W tabeli 8 i 9 zamieszczono odpowiednio medianę i odchylenie standardowe w przekroju rocznych wyników.

Tabela 6

Tendencje zmian percepcji jakości środowiska instytucjonalnego w Polsce w latach 2009-2015 w przekroju corocznych badań ankietowych

\begin{tabular}{|c|c|c|c|c|c|c|c|}
\hline Wyszczególnienie & 2009 & 2010 & 2011 & 2012 & 2013 & 2014 & 2015 \\
\hline \multicolumn{8}{|c|}{ Instytucje publiczne i funkcjonowanie prawa } \\
\hline $\begin{array}{l}\text { I.1. Prawo i przepisy są tak skompliko- } \\
\text { wane... }\end{array}$ & - & + & - & + & - & $+1-$ & + \\
\hline $\begin{array}{l}\text { I.2. Załóżmy, że napotykasz nieuczciwe } \\
\text { postępowanie... }\end{array}$ & - & + & - & + & + & + & - \\
\hline $\begin{array}{l}\text { I.3. Jako przedsiębiorca zawsze obawiasz } \\
\text { się... }\end{array}$ & - & + & $+/-$ & - & + & + & + \\
\hline $\begin{array}{l}\text { I.4. Czy znajomość osobista z urzędni- } \\
\text { kiem przyspiesza... }\end{array}$ & $+/-$ & + & - & + & + & - & + \\
\hline $\begin{array}{l}\text { I.5. Czy znajomość osobista z urzędni- } \\
\text { kiem wpływa... }\end{array}$ & - & + & - & + & + & $+/-$ & + \\
\hline \multicolumn{8}{|c|}{ Stanowienie prawa } \\
\hline $\begin{array}{l}\text { S.1. Czy jako przedsiębiorca masz regu- } \\
\text { larnie do czynienia... }\end{array}$ & + & + & - & + & + & + & - \\
\hline $\begin{array}{l}\text { S.2. Czy jako przedsiębiorca jesteś ofi- } \\
\text { cjalnie... }\end{array}$ & $+1-$ & + & - & $+/-$ & $+/-$ & $+/-$ & - \\
\hline
\end{tabular}




\begin{tabular}{|l|c|c|c|c|c|c|c|}
\hline $\begin{array}{l}\text { S.3. Czy w przypadku znacznych zmian } \\
\text { w prawie... }\end{array}$ & + & - & - & - & + & $+/-$ & - \\
\hline $\begin{array}{l}\text { S.4. Czy oczekujesz od rządu realizowa- } \\
\text { nia ważnych... }\end{array}$ & - & $+/-$ & $+/-$ & $+/-$ & + & - & + \\
\hline \multicolumn{7}{|c|}{ Egzekwowanie prawa } \\
\hline $\begin{array}{l}\text { E.1. Załóżmy, że Twój prywatny spór } \\
\text { trafia do sądu... }\end{array}$ & + & + & - & $+/-$ & - & + & + \\
\hline $\begin{array}{l}\text { E.2. Strona, która więcej płaci wygra } \\
\text { sprawę... }\end{array}$ & + & + & $+/-$ & $+/-$ & $+/-$ & + & - \\
\hline $\begin{array}{l}\text { E.3. Czy jest bez znaczenia, który sędzia } \\
\text { decyduje o sprawie... }\end{array}$ & $+/-$ & + & - & + & - & - & $+/-$ \\
\hline $\begin{array}{l}\text { E.4. Gdybyś został niesprawiedliwie } \\
\text { potraktowany w sądzie... }\end{array}$ & - & - & + & - & + & + & + \\
\hline
\end{tabular}

Legenda: + poprawa sytuacji w porównaniu z poprzednim rokiem; +/- brak zmian lub bardzo niewielkie zmiany w porównaniu z rokiem poprzednim; - pogorszenie sytuacji w porównaniu z poprzednim rokiem.

Źródło: własne badania ankietowe.

Tabela 7

Tendencje zmian percepcji w sferze niepewności. Przekrój roczny

\begin{tabular}{|l|c|c|c|c|c|c|c|}
\cline { 2 - 8 } \multicolumn{1}{l|}{} & 2009 & $\mathbf{2 0 1 0}$ & $\mathbf{2 0 1 1}$ & $\mathbf{2 0 1 2}$ & $\mathbf{2 0 1 3}$ & $\mathbf{2 0 1 4}$ & $\mathbf{2 0 1 5}$ \\
\hline $\begin{array}{l}\text { Niepewność w sferze funkcjonowa- } \\
\text { nia instytucji publicznych }\end{array}$ & $+/-$ & - & - & - & + & + & - \\
\hline $\begin{array}{l}\text { Niepewność w sferze stanowienia } \\
\text { prawa }\end{array}$ & + & - & - & - & + & + & - \\
\hline $\begin{array}{l}\text { Niepewność w sferze egzekwowanie } \\
\text { prawa }\end{array}$ & - & - & - & - & - & + & - \\
\hline
\end{tabular}

Legenda: + poprawa sytuacji w porównaniu z poprzednim rokiem, czyli spadek niepewność; +/- brak lub niewielkie zmiany w porównaniu z rokiem poprzednim; - pogorszenie się sytuacji w porównaniu z poprzednim rokiem, czyli wzrost niepewności.

Źródło: własne badania ankietowe.

Informacje zestawione w tabeli 6 pokazuja, że w siedmioletnim przedziale najszersza poprawę odnotowano w 2010 r., gdzie odpowiedzi respondentów z wyjątkiem pytań S3, S4 i E4 wskazywały na poprawę w otoczeniu instytucjonalnym. Względnie dobry odbiór zmian w otoczeniu odnotowano także w 2013 r. - poprawa w ośmiu na trzynaście obszarów oraz w roku wyborczym (dziesięć pierwszych miesięcy 2015) - poprawa w siedmiu na trzynaście obszarów. Analizując uzyskane wyniki w przekroju czasu, warto odnotować poprawę stopnia przewidywalności nowych regulacji (S1) - pięć na siedem lat; oraz poprawę w sferze I2, I3, I4, I5, a także E1 i E4 w czterech na siedem rocznych badaniach. Łącznie wyniki analizy kierunków rocznych zmian pokazuja, że respondenci uznali, że poprawa w sferze Instytucji i funkcjonowania prawa była względnie najmocniej widoczna. Analiza wyników 10-letnich ocen kro- 
czących (tab. 7) wyraźnie wskazuje, że łącznie percepcja zmian w postrzeganiu niepewności nie była pomyślna. Tylko w 2014 r. respondenci uznali, że poziom niepewności we wszystkich trzech obszarach się obniżył. Najwyższą krocząca niepewność trzeba odnotować w sferze egzekwowania prawa - tylko w jednym roku (2014) odnotowano zmniejszenie niepewności. Analizując kierunki zmian w percepcji jakości instytucji publicznych i funkcjonowania prawa, a także w sferze stanowienia i egzekwowania prawa, trzeba odnotować, że skala tych zmian w przekrojach rocznych nie była bardzo wyraźna. Widać to, gdy przyjrzymy się medianom i odchyleniom standardowym.

Tabela 8 zwiera zestawienie wartości mediany dla odpowiedzi na pytania ankietowe w przekroju rocznym. W tabeli 9 zestawiono wartości odchylenia standardowego tych odpowiedzi. Odchylenie standardowe dostarcza informacji o zmienności wyników: im wyższa wartości odchylenia standardowego, tym wyższe jest rozproszenie uzyskanych wyników wokół ich średniej. Mediana jest miarą centralną dzieląco każdorazowy zbiór odpowiedzi na dwie równe części. W tabeli zamieszczono wyniki uzyskane z szeregów rozdzielczych przedziałowych za pomoca pakietu SPSS. Wyniki zawarte w tabeli 8 wskazuja wysoką stabilność percepcji otoczenia w przekrojach poszczególnych lat.

\section{Tabela 8}

Mediana odpowiedzi w przekroju rocznym w latach 2009-2015

\begin{tabular}{|c|c|c|c|c|c|c|c|}
\hline Wyszczególnienie & 2009 & 2010 & 2011 & 2012 & 2013 & 2014 & 2015 \\
\hline \multicolumn{8}{|c|}{ Instytucje publiczne i funkcjonowanie prawa } \\
\hline $\begin{array}{l}\text { I1. Prawa i przepisy są tak skompliko- } \\
\text { wane... }\end{array}$ & 4,00 & 4,00 & 4,00 & 4,00 & 4,00 & 4,00 & 4,00 \\
\hline $\begin{array}{l}\text { I2. Załóżmy, że napotykasz nieuczciwe } \\
\text { postępowanie... }\end{array}$ & 4,00 & 5,00 & 4,00 & 5,00 & 5,00 & 5,00 & 5,00 \\
\hline $\begin{array}{l}\text { I3. Jako przedsiębiorca zawsze obawiasz } \\
\text { się... }\end{array}$ & 3,00 & 2,00 & 2,00 & 3,00 & 2,00 & 2,00 & 2,00 \\
\hline $\begin{array}{l}\text { I4. Czy znajomość osobista z urzędni- } \\
\text { kiem przyspiesza... }\end{array}$ & 5,00 & 5,00 & 5,00 & 5,00 & 4,00 & 5,00 & 4,00 \\
\hline $\begin{array}{l}\text { I5. Czy znajomość osobista } \\
\text { z urzędnikiem wpływa... }\end{array}$ & 4,00 & 3,00 & 3,00 & 3,00 & 3,00 & 3,00 & 3,00 \\
\hline $\begin{array}{l}\text { I6. Czy w ciagu ostatnich } 10 \text { lat niepew- } \\
\text { ność co do działania... }\end{array}$ & 2,00 & 2,00 & 2,00 & 2,00 & 2,00 & 2,00 & 2,00 \\
\hline \multicolumn{8}{|c|}{ Stanowienie prawa } \\
\hline $\begin{array}{l}\text { S1. Czy jako przedsiębiorca masz regu- } \\
\text { larnie do czynienia... }\end{array}$ & 4,00 & 4,00 & 4,00 & 4,00 & 4,00 & 4,00 & 4,00 \\
\hline $\begin{array}{l}\text { S2. Czy jako przedsiębiorca jesteś ofi- } \\
\text { cjalnie... }\end{array}$ & 4,00 & 4,00 & 4,00 & 3,00 & 4,00 & 4,00 & 4,00 \\
\hline $\begin{array}{l}\text { S3. Czy w przypadku znacznych zmian } \\
\text { w prawie... }\end{array}$ & 2,00 & 2,00 & 2,00 & 2,00 & 2,00 & 2,00 & 2,00 \\
\hline $\begin{array}{l}\text { S4. Czy oczekujesz po rzadzie realizowa- } \\
\text { nia ważnych projektów... }\end{array}$ & 2,00 & 2,00 & 3,00 & 2,00 & 3,00 & 2,00 & 2,00 \\
\hline
\end{tabular}




\begin{tabular}{|l|c|c|c|c|c|c|c|c|}
\hline $\begin{array}{l}\text { S5. Czy w ciagu ostatnich 10 lat niepew- } \\
\text { ność w stanowieniu... }\end{array}$ & 2,00 & 2,00 & 2,00 & 2,00 & 2,00 & 2,00 & 2,00 \\
\hline \multicolumn{7}{|c|}{ Egzek wowanie prawa } \\
\hline $\begin{array}{l}\text { E1. Załóżmy, że Twój prywatny spór } \\
\text { trafia do sądu... }\end{array}$ & 4,00 & 4,00 & 4,00 & 4,00 & 4,00 & 4,00 & 4,00 \\
\hline $\begin{array}{l}\text { E2. Strona, która więcej płaci, wygra } \\
\text { sprawę... }\end{array}$ & 4,00 & 3,00 & 3,00 & 3,00 & 3,00 & 3,00 & 3,00 \\
\hline $\begin{array}{l}\text { E3. Czy jest bez znaczenia, który sędzia } \\
\text { decyduje... }\end{array}$ & 4,00 & 3,00 & 3,00 & 3,00 & 3,00 & 3,00 & 3,00 \\
\hline $\begin{array}{l}\text { E4. Gdybý́ został niesprawiedliwie } \\
\text { potraktowany w sądzie... }\end{array}$ & 5,00 & 5,00 & 5,00 & 5,00 & 5,00 & 5,00 & 5,00 \\
\hline $\begin{array}{l}\text { E5. Czy w ciagu ostatnich 10 lat niepew- } \\
\text { ność w egzekucji... }\end{array}$ & 2,00 & 2,00 & 2,00 & 2,00 & 2,00 & 2,00 & 2,00 \\
\hline
\end{tabular}

Źródło: obliczenia na za pomoca pakietu SPSS podstawie wyników badań ankietowych.

Uwagę zwraca stała wartość mediany odpowiedzi na pytanie pierwsze (I1): respondenci w kolejnych siedmiu latach uznawali, że często stawali wobec sytuacji, w której przepisy były tak skomplikowane, niejasne, a czasami wykluczające się, że nie sposób było stosować się do nich poprawnie. Stąd w ocenach respondentów urzędnicy często mogli utrudnić interesantom życie poprzez opóźnianie lub arbitralne decyzje. Ogólny obraz wyłaniający się analizy ilościowej pokazuje względnie silnie ugruntowane opinie o z jednej strony uznaniowości urzędniczej i roli kontaktów (tab. 8, mediany odpowiedzi na pytania I3 i I4), z drugiej o gotowości respondentów do przeciwstawiania się nieuczciwym praktykom (tab. 8 mediana odpowiedzi na pytanie I2). Tłem dla tych deklarowanych w odpowiedziach zachowań są ugruntowane oceny respondentów o jakości stanowienia prawa (tab. 8, mediany odpowiedzi na pytania S1-S4). Mediana na poziomie 4 we wszystkich siedmiu latach oznacza, że w opinii respondentów zmiany przepisów prawa były często nieprzewidywalne (odpowiedzi na pytanie S1). Respondenci wskazuja, że rzadko są konsultowani (S3). Nie mają wygórowanych oczekiwań co do rzetelności polityków; rzadko ufają rządowym publicznym zapowiedziom (S4). Mediany ocen sfery egzekwowania prawa (E1-E4) sa także trwałe. Wiara w obiektywizm sądów (E1) jest stosunkowo wysoka; wartość mediany na poziomie 4 oznacza, że respondenci często ufali, że wyznaczony sędzia obiektywnie wymierzy sprawiedliwość. Inne wyniki (S2 i S3) wskazuja jednak, że w ocenie respondentów czasami dochodziło do subiektywizmu w ferowaniu wyroków przez sędziów. Na podkreślenie zasługuje stałe deklarowanie przez respondentów gotowości do dochodzenia swoich praw na drodze sądowej przez wnoszenie sprawy do wyższej instancji w sytuacjach nieuczciwego postepowania sędziów lub przekonania o niesprawiedliwym wyroku. Interesujacy obraz percepcji stanu otoczenia instytucjonalnego wyłania się z analizy mediany odpowiedzi na pytania o tendencje w kształtowaniu się ogólnej niepewności we wszystkich trzech sferach (tab. 8, mediany odpowiedzi na pytania I6, S5 i E5). We wszystkich latach mediana 10-letnich kroczacych odpowiedzi była niezmienna - wskazywała, że respondenci nie odczuwali zmian w poziomie niepewności. Względna stabilność tych ocen widać także na podstawie analiz war- 
tości odchylnia standardowego (tab. 9). Na podstawie analizy wyników w tabeli 9 widać, że największą zbieżność wykazywały oceny w odniesieniu do kwestii komplikacji prawa i na tym tle uznaniowości urzędników (I1), a także zmienności prawa (S1 i S3). Względnie niewielkie rozproszenie odpowiedzi dotyczyło subiektywizmu sędziów (tab. 9, E2 i E3), przy czym w tych dwóch przypadkach wartości odchylenia standardowego wzrastały.

Tabela 9

Odchylenie standardowe odpowiedzi w przekroju rocznym w latach 2009-2015

\begin{tabular}{|c|c|c|c|c|c|c|c|}
\hline Lata & 2009 & 2010 & 2011 & 2012 & 2013 & 2014 & 2015 \\
\hline \multicolumn{8}{|c|}{ Instytucje publiczne i funkcjonowanie prawa } \\
\hline $\begin{array}{l}\text { I1. Prawa i przepisy sa tak } \\
\text { skomplikowane... }\end{array}$ & 0,95 & 0,94 & 1,03 & 0,97 & 1,01 & 0,87 & 0,91 \\
\hline $\begin{array}{l}\text { I2. Załóżmy, że napotykasz nieuczciwe } \\
\text { postępowanie... }\end{array}$ & 1,49 & 1,59 & 1,64 & 1,54 & 1,48 & 1,58 & 1,54 \\
\hline $\begin{array}{l}\text { I3. Jako przedsiębiorca zawsze obawiasz } \\
\text { się... }\end{array}$ & 1,30 & 1,34 & 1,30 & 1,39 & 1,40 & 1,38 & 1,28 \\
\hline $\begin{array}{l}\text { I4. Czy osobista znajomość z urzędnikiem } \\
\text { przyspiesza... }\end{array}$ & 1,04 & 1,20 & 1,08 & 1,10 & 1,23 & 1,10 & 1,24 \\
\hline $\begin{array}{l}\text { I5. Czy osobista znajomość z urzędnikiem } \\
\text { wpływa... }\end{array}$ & 1,46 & 1,37 & 1,38 & 1,42 & 1,35 & 1,36 & 1,43 \\
\hline $\begin{array}{l}\text { I6. Czy w ciagu ostatnich } 10 \text { lat } \\
\text { niepewność co do działania... }\end{array}$ & 0,75 & 0,75 & 0,74 & 0,72 & 0,78 & 0,74 & 0,75 \\
\hline \multicolumn{8}{|c|}{ Stanowienie prawa } \\
\hline $\begin{array}{l}\text { S1. Czy jako przedsiębiorca masz } \\
\text { regularnie do czynienia... }\end{array}$ & 0,94 & 0,87 & 0,84 & 0,92 & 0,95 & 0,92 & 0,82 \\
\hline $\begin{array}{l}\text { S2. Czy jako przedsiębiorca jesteś } \\
\text { oficjalnie... }\end{array}$ & 1,13 & 1,13 & 1,23 & 1,28 & 1,23 & 1,30 & 1,24 \\
\hline $\begin{array}{l}\text { S3. Czy w przypadku znacznych zmian } \\
\text { w prawie... }\end{array}$ & 1,10 & 1,05 & 1,16 & 1,07 & 1,03 & 1,15 & 1,09 \\
\hline $\begin{array}{l}\text { S4. Czy oczekujesz po rządzie } \\
\text { realizowania ważnych projektów... }\end{array}$ & 1,13 & 1,35 & 1,36 & 1,36 & 1,56 & 1,37 & 1,42 \\
\hline $\begin{array}{l}\text { S5. Czy w ciagu ostatnich } 10 \text { lat } \\
\text { niepewność w stanowieniu... }\end{array}$ & 0,68 & 0,74 & 0,78 & 0,68 & 0,75 & 0,72 & 0,69 \\
\hline \multicolumn{8}{|c|}{ Egzekwowanie prawa } \\
\hline $\begin{array}{l}\text { E1. Załóżmy, że Twój prywatny spór } \\
\text { trafia do sądu... }\end{array}$ & 1,09 & 1,09 & 1,16 & 1,22 & 1,26 & 1,23 & 1,28 \\
\hline $\begin{array}{l}\text { E2. Strona, która więcej płaci, wygra } \\
\text { sprawę... }\end{array}$ & 1,06 & 1,11 & 1,09 & 1,12 & 1,04 & 1,14 & 1,20 \\
\hline $\begin{array}{l}\text { E3. Czy jest bez znaczenia, który sędzia } \\
\text { decyduje... }\end{array}$ & 1,25 & 1,28 & 1,20 & 1,20 & 1,21 & 1,19 & 1,31 \\
\hline $\begin{array}{l}\text { E4. Gdybyś został niesprawiedliwie } \\
\text { potraktowany w sądzie... }\end{array}$ & 1,27 & 1,35 & 1,26 & 1,44 & 1,28 & 1,38 & 1,22 \\
\hline $\begin{array}{l}\text { E5. Czy w ciagu ostatnich } 10 \text { lat } \\
\text { niepewność w egzekucji... }\end{array}$ & 0,68 & 0,62 & 0,71 & 0,69 & 0,73 & 0,67 & 0,64 \\
\hline
\end{tabular}

Źródło: obliczono na podstawie wyników badań ankietowych. 


\subsection{Przekrój okresów odpowiedzialności legislacyjnej}

Wykresy 3, 4, 5 i 6 przedstawiają odpowiednio uśrednione oceny w trzech powyższych obszarach i w zakresie ogólnej percepcji niepewności dla Sejmu VI i VII kadencji na tle okresu od 1997 r. W opracowaniu zgodnie z realiami polskiej praktyki parlamentarnej, a w tym z czasem potrzebnym na sformowanie i zaprzysiężenie rządu przyjęto, że dany skład parlamentu i wyłoniony na tej podstawie gabinet odpowiadają legislacyjnie za okres, począwszy od następnego roku kalendarzowego po roku wyborów aż do kolejnego wyborczego roku włącznie. Tak więc w przedziale czasu objętym własnymi badaniami ankietowymi wyodrębniono następujace cztery okresy odpowiedzialności legislacyjnej: 1998-2001, 2002-2005, 2006-2007 oraz 2008-2011-2011-2015. Tabela 10 zawiera zestawienie rankingowe dla tak określonych okresów. Ostatni przedział jest wyjątkowy - pierwszy raz w historii po przemianach 1989 r. ta sama koalicja mogła utrzymać odpowiedzialność legislacyjną przez dwa kolejne okresy.

\section{Wykres 3}

Percepcja jakości i stylu działania instytucji publicznych w przekroju okresów odpowiedzialności legislacyjnej w Polsce w latach 1997-2015

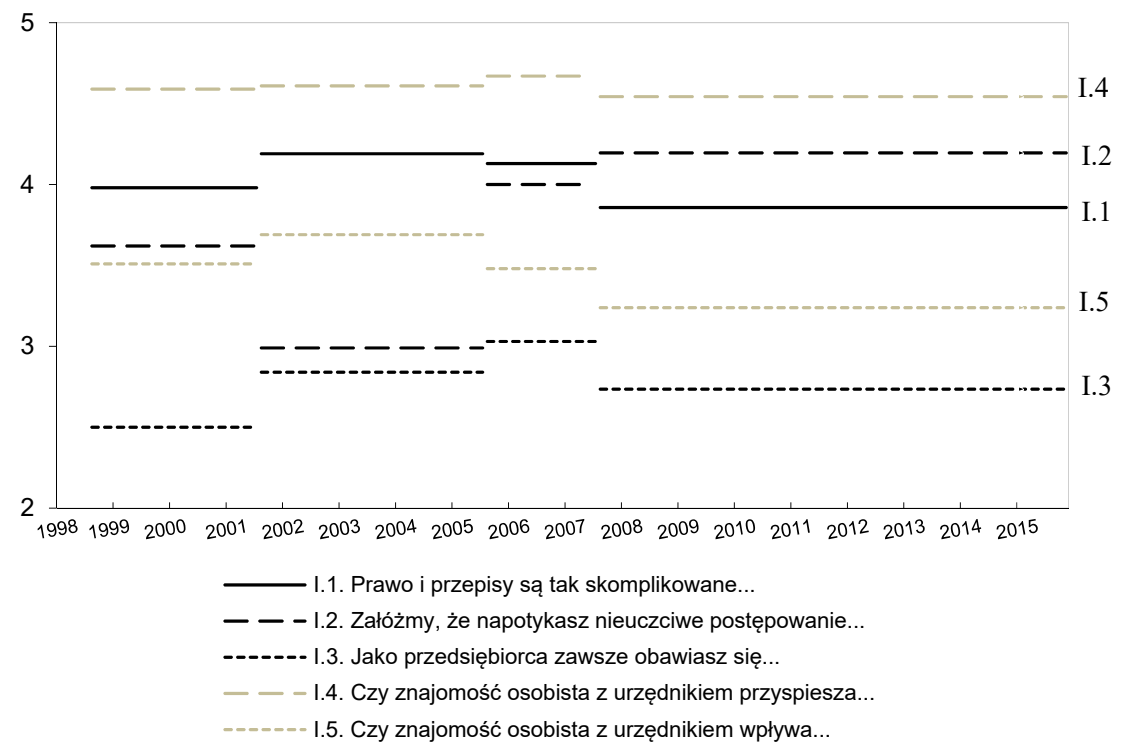

Źródło: obliczenia na podstawie własnych badań ankietowych.

Porównania i ocena okresów pod kątem zmian percepcji stanu otoczenia instytucjonalnego biznesu nie jest wolna od trudności i kontrowersji. Jest tak dlatego, że w kolejnych przedziałach czasu koniunktura gospodarcza i warunki w otoczeniu międzynarodowym były odmienne. Przykładem mogą być zakłócenia związane z kryzysem w krajach Azji Wschodniej w latach 1997-1998 i jego reperkusje dla Federacji Rosyjskiej (częściowa niewypłacalność w 1998 r. i jej skutki dla wymiany handlowej). 


\section{Tabela 10}

Ranking poszczególnych okresów odpowiedzialności legislacyjnej w przekroju poszczególnych pytań ankietowych*

\begin{tabular}{|c|c|c|c|c|}
\hline \multirow{2}{*}{ Wyszczególnienie } & \multicolumn{4}{|c|}{$\begin{array}{l}\text { Ranking według okresów } \\
\text { odpowiedzialności }\end{array}$} \\
\hline & $\begin{array}{l}1998- \\
-2001\end{array}$ & $\begin{array}{l}2002- \\
-2005\end{array}$ & $\begin{array}{l}2006- \\
-2007\end{array}$ & $\begin{array}{l}2008- \\
-2015\end{array}$ \\
\hline \multicolumn{5}{|c|}{ Instytucje publiczne i funkcjonowanie prawa } \\
\hline I1. Prawa i przepisy są tak skomplikowane... & 2 & 4 & 3 & 1 \\
\hline $\begin{array}{l}\text { I2. Załóżmy, że napotykasz nieuczciwe } \\
\text { postępowanie... }\end{array}$ & 4 & 3 & 2 & 1 \\
\hline I3. Jako przedsiębiorca zawsze obawiasz się... & 1 & 3 & 4 & 2 \\
\hline $\begin{array}{l}\text { I4. Czy osobista znajomość z urzędnikiem } \\
\text { przyspiesza... }\end{array}$ & 2 & 3 & 4 & 1 \\
\hline I5. Czy osobista znajomość z urzędnikiem wpływa... & 3 & 4 & 2 & 1 \\
\hline $\begin{array}{l}\text { I6. Czy w ciagu ostatnich } 10 \text { lat niepewność co do } \\
\text { działania... }\end{array}$ & 2 & 1 & 4 & 3 \\
\hline \multicolumn{5}{|c|}{ Stanowienie prawa } \\
\hline $\begin{array}{l}\text { S1. Czy jako przedsiębiorca masz regularnie do } \\
\text { czynienia... }\end{array}$ & 1 & 2 & 3 & 2 \\
\hline S2. Czy jako przedsiębiorca jesteś oficjalnie... & 1 & 3 & 2 & 4 \\
\hline S3. Czy w przypadku znacznych zmian w prawie... & 3 & 1 & 4 & 2 \\
\hline $\begin{array}{l}\text { S4. Czy oczekujesz po rządzie realizowania ważnych } \\
\text { projektów... }\end{array}$ & 2 & 4 & 3 & 1 \\
\hline $\begin{array}{l}\text { S5. Czy w ciagu ostatnich } 10 \text { lat niepewność } \\
\text { w stanowieniu... }\end{array}$ & 3 & 1 & 3 & 2 \\
\hline \multicolumn{5}{|c|}{ Egzekwowanie prawa } \\
\hline E1. Załóżmy, że Twój prywatny spór trafia do sądu... & 1 & 4 & 2 & 3 \\
\hline E2. Strona, która więcej płaci, wygra sprawę... & 2 & 3 & 1 & 1 \\
\hline E3. Czy jest bez znaczenia, który sędzia decyduje... & 4 & 3 & 2 & 1 \\
\hline $\begin{array}{l}\text { E4. Gdybyś został niesprawiedliwie potraktowany } \\
\text { w sądzie... }\end{array}$ & 2 & 3 & 1 & 4 \\
\hline $\begin{array}{l}\text { E5. Czy w ciagu ostatnich } 10 \text { lat niepewność } \\
\text { w egzekucji... }\end{array}$ & 2 & 1 & 4 & 3 \\
\hline Suma pozycji w rankingu & 35 & 43 & 44 & 32 \\
\hline
\end{tabular}

*1 - oznacza najwyższą względną ocenę respondentów; 4 - odpowiednio najniższą wśród czterech wyodrębnionych okresów odpowiedzialności legislacyjnej. Ta sama ocena oznacza pozycję ex aequo.

Źródło: obliczenia własne na podstawie odpowiedzi respondentów uzyskanych za pomocą ankiet w latach 1997-2015. 
Innym przykładem negatywnego szoku w otoczeniu zewnętrznym był globalny kryzys lat 2008-2009 i jego długotrwałe reperkusje w krajach strefy euro i całej Unii Europejskiej. Negatywne zjawiska w otoczeniu Polski były poza jej kontrola. Wpływały jednak na nastroje - wymagały od rządów i prawodawców odpowiednich dostosowań regulacyjnych. Były one nastawione na zapewnienie bezpieczeństwa makroekonomicznego i siła rzeczy mogły negatywnie wpływać na ówczesną aktywność gospodarczą i pośrednio na percepcję sytuacji w otoczeniu instytucjonalnym. W okresie objętym analizą były także lata o bardzo korzystnej koniunkturze. Do tych okresów zaliczyć należy przyjęcie Polski do Unii Europejskiej w połowie 2004 r., co dało bardzo silny pozytywny impuls gospodarczy przez skokowy wzrost eksportu i dostęp do Funduszy Strukturalnych. Okres ten trwał aż do $2008 \mathrm{r}$.

Mając na względzie powyższe uwagi oraz różną długość poszczególnych okresów odpowiedzialności legislacyjnej, należy odnotować, że w ocenie respondentów najwyższe względne oceny w obszarze instytucji publicznych i funkcjonowania prawa odnotowano dla okresu 2008-2015 (wykres 3 i tab. 10). Tylko w przypadku ocen odnośnie do pytania I3 (kwestia uznaniowości i patologii urzędniczej) lepsze wyniki ankietowe zanotowano dla okresu 1998-2001. W ocenie ogólnego poczucia niepewności (pytania odpowiednio I6, S5 i E5) względne oceny respondentów odnośnie do okresu 2008-2015 nie były najwyższe (wykresy 3-6 oraz tab. 10). Pod tym względem systematycznie najlepiej oceniano okres 2002-2005.

\section{Wykres 4}

Percepcja jakości i stylu stanowienia prawa w przekroju okresów odpowiedzialności legislacyjnej w Polsce w latach 1997-2015

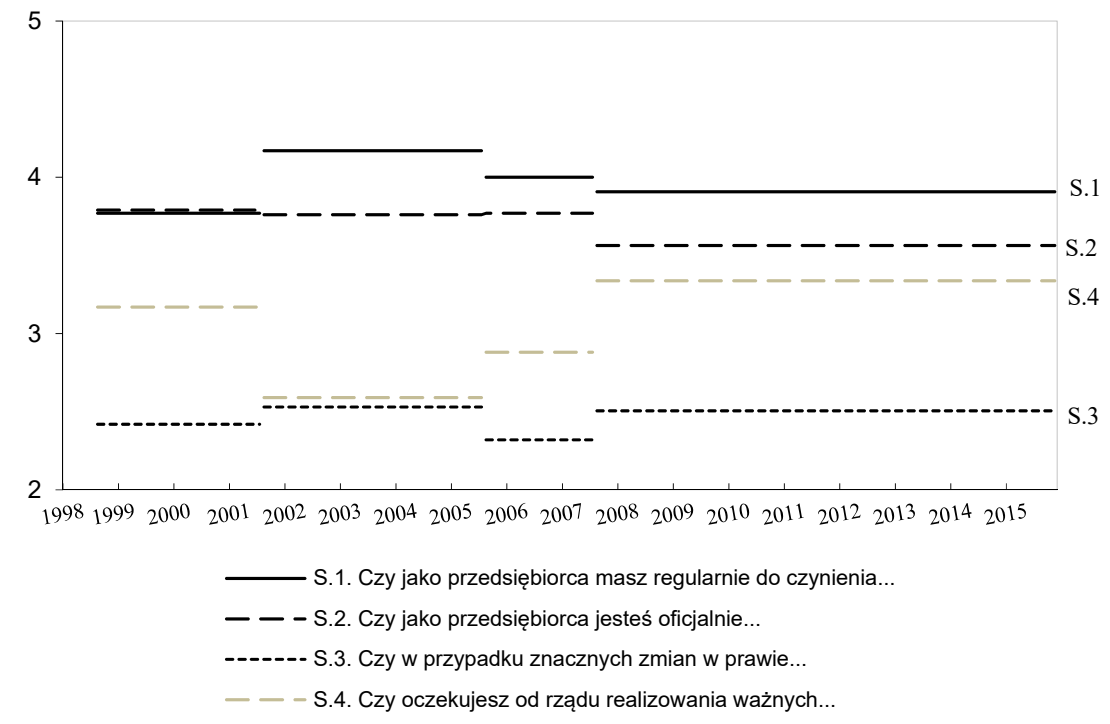

Źródło: jak na wykresie 3. 


\section{Wykres 5}

Percepcja jakości i stylu egzekwowania prawa w przekroju okresów odpowiedzialności legislacyjnej w Polsce w latach 1997-2015

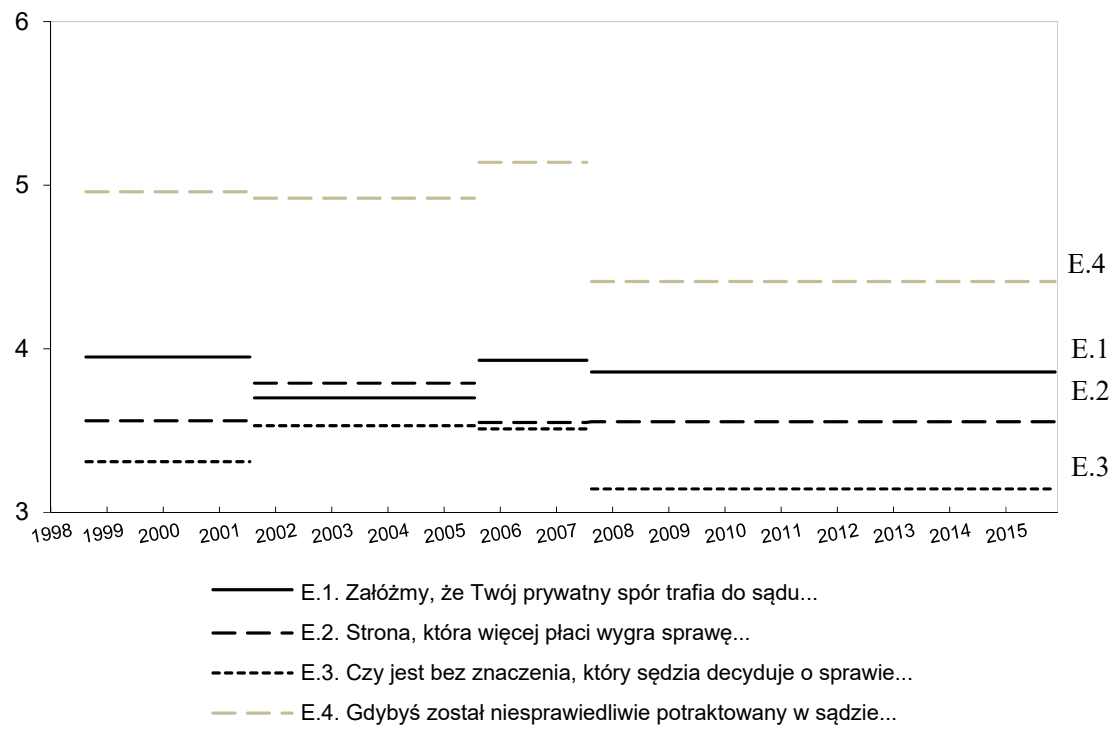

Źródło: jak na wykresie 3.

Średnia ocen dla obszaru stanowienia prawa (pytania S1-S4) wyliczona dla poszczególnych okresów odpowiedzialności legislacyjnej pokazuje, że lata 2008-2015 nie były pod tym względem najlepsze. Jak wynika z wykresu 4 i tabeli 10 najwyższe względne oceny dotyczyły podokresu 1998-2001, ale lata 2008-2015 były wyżej oceniane niż 2002-2005 i 2006-2007. Także oceny w obszarze egzekwowania prawa (pytania E1-E4) dla lat 2008-2015 nie były udane. W tym obszarze najkorzystniejsze średnie oceny odnotowano dla lat 20062007. W świetle wyników ankietowych okresy 2008-2015 i 1998-2001 były tak samo ocenione (suma pozycji rankingowych - 9). Respondenci ten obszar otoczenia instytucjonalnego względnie najniżej ocenili w latach 2002-2005. Analizując przedstawione wyniki, należy pamiętać, że mogą być one obarczone błędem wynikającym z faktu, że nie uzyskano ich z próby losowej. Z drugiej strony podkreślić należy, że oceny wyrażane przez osoby z wyższym wykształceniem zajmujacce się $\mathrm{w}$ praktyce biznesem podnoszą wartość poznawczą tak zgromadzonego materiału.

Porównując okresy odpowiedzialności legislacyjnej, trzeba pamiętać, że w przypadku krótkich epizodów (lata 2006-2007) na średnie wyniki wpływ mogą mieć wartości skrajne. Z drugiej strony oceny odnoszace się dwóch pełnych kadencji (lata 2008-2015) mogą także odzwierciedlać znużenie i zniecierpliwienie tą samą ekipą. Porównując średnie oceny wyliczone dla poszczególnych okresów i obszarów problemowych, trzeba zauważyć, że w wielu przypadkach różnice między pierwszy i drugim miejscem w rankingu 


\section{Wykres 6}

Percepcja ogólnej niepewności w odniesieniu do ... w przekroju wyodrębnionych okresów odpowiedzialności legislacyjnej w Polsce w latach 1997-2015

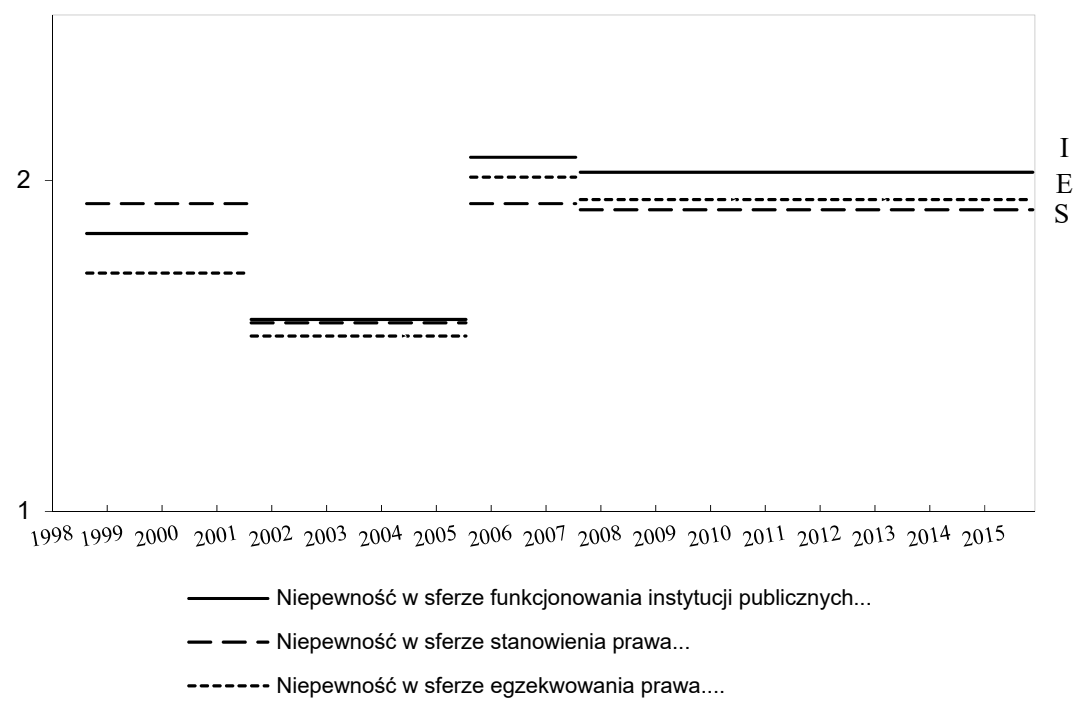

Źródło: jak na wykresie 3.

(tab. 10 i wykresy 3-6) były bardzo niewielkie. Tak było w przypadku ocen sfery instytucji i funkcjonowania prawa (pytania I1 i I4), stanowienia prawa (obszary opisane pytaniami S2-S3), czy egzekwowania prawa (E1 i E2). Były jednak obszary ocen, w których różnice między najwyższymi ocenami respondentów i pozostałymi były względnie duże. Należały do nich kwestie przedstawiane w pytaniach I2, I3, I5, S1, E3 i E4 (wykres 3, 4 i 5). Sumując pozycje rankingowe powstałe na podstawie wartości średnich ocen wyliczonych dla poszczególnych obszarów i okresów (zob. ostatni wiersz tab. 10), można zauważyć, że względnie najlepszą ocenę respondentów (32) uzyskał okres odpowiedzialności 2008-2015, a następnie okres 1998-2001 (suma pozycji rankingowych 35). Porządkując zbiór wyników i agregując oceny wyrażane przez respondentów, trzeba zauważyć, że nawet najwyższe oceny były względnie odległe od teoretycznych wielkości optymalnych. Ta empiryczna prawidłowość, mimo niewątpliwego postępu, potwierdza skalę dystansu polskiej praktyki funkcjonowania otoczenia i prawodawstwa względem najlepszych konkurentów.

\section{PODSUMOWANIE}

Przedstawione w opracowaniu dane o percepcji funkcjonowania otoczenia instytucjonalnego rozumianego jako ogół działań instytucji państwa oraz procesy stanowienia i egzekwowania prawa potwierdzaja potoczne opinie o jego 
niezadowalajacym stanie. Polska i kraje Środkowej Europy musiały wdrożyć nowoczesny porządek prawny odpowiadający wymogom gospodarki rynkowej i następnie członkostwa w Unii Europejskiej. Wielkie zmiany ustrojowe wiązały się z nadziejami na stworzenie sprawnego i sprawiedliwego państwa prawnego. Tylko nieliczna grupa reformatorów miała wiedzę i doświadczenia akademickie ugruntowane w nowoczesnych demokracjach parlamentarnych. Ogromna większość biernych uczestników tego procesu, nie mając takich doświadczeń była i jest poddana zależności od ścieżki. Ich oceny przebiegu transformacji instytucjonalnej i gospodarczej sa obarczone z jednej strony obciążeniami przeszłości, z drugiej często nierealistycznymi oczekiwaniami co do funkcjonowania agend państwa, demokratycznych procedur stanowienia prawa i jego egzekwowania. Właśnie zderzenie ugruntowanych doświadczeń sprzed zmian ustrojowych, wyidealizowanych oczekiwań i faktycznych niedomagań instytucjonalnych może przekładać się na skrzywienie poznawcze i po części wynikające z tego nadmiernie krytyczne oceny realnych i instytucjonalnych procesów.

Niewystarczająca jakość otoczenia instytucjonalnego w Polsce i innych krajach regionu jest akcentowana także w ocenach składających się na rankingi międzynarodowej konkurencyjności. W tych opiniotwórczych raportach szeroko pojmowane otoczenie instytucjonalne systematycznie zaliczane jest do słabości Polski. W świetle przedstawionych w opracowaniu wyników i przy zastrzeżeniach co do faktycznej skali niedomagań w sferze funkcjonowania agend państwa, stanowienia i egzekwowania prawa trzeba zauważyć, że konkurencyjność międzynarodowa gospodarek postrzegana jest współcześnie właśnie przez pryzmat jakości otoczenia biznesu, a w tym otoczenia instytucjonalnego. Zaniedbania w tej sferze, zwiększając koszty transakcyjne zniekształcają przebieg bieżących procesów gospodarczych i poprzez kanał oczekiwań negatywnie wpływają na skalę i kierunki inwestycji.

Wynik prezydenckich i październikowych wyborów parlamentarnych w 2015 r. ukształtował nową strukturę Sejmu. Stosunek prezydenta i większość parlamentarnej do zastanego porządku prawnego, specyficzna praktyka stanowienia prawa przez tę formację i przede wszystkim marginalizowanie Trybunału Konstytucyjnego, praktyczna likwidacja służby cywilnej i przywrócenie nomenklatury, podporządkowanie mediów publicznych partii, zmiany w obszarze prokuratury oraz powstanie poza konstytucyjnego centrum decyzyjnego i faktyczna fasadowość aparatu państwowego, stanowia realne zagrożenie dla funkcjonowania państwa prawa. Kształtowany przez dyktat większości schemat partyjnego modelu państwa, w sensie zależności od ścieżki, należy traktować jako realne niebezpieczeństwo przesunięcia do wyjściowego modelu, odrzuconego w wyborach w $1989 \mathrm{r}$.

prof. dr hab. Tadeusz Kowalski Uniwersytet Ekonomiczny w Poznaniu tadeusz.kowalski@ue.poznan.pl 


\section{PUBLIC INSTITUTIONS, LAW MAKING AND LAW ENFORCEMENT \\ IN POLAND IN 2009-2015: \\ THE MANAGERS' PERSPECTIVE}

\section{Summary}

The aim of the article is to present and assess the evolution of managers' perception of institutional changes in Poland in 2009-2015. The significant deficiencies in public institutions as well as the quality of law are criticised by citizens, businessmen and politicians. There are no doubts that some institutional improvements have been made but criticism comes also from foreign experts and business organisations. The article shows and assesses the empirical results of the continuous research that the author began in 1997. A special emphasis, however, was on the findings of the period 2009-2015. The transmission of shifts in an institutional environment into current and long-term decisions made by economic agents is also discussed.

JEL: K00; D78; P37 
